\title{
Pathogens which threaten food security: Phytophthora infestans, the potato late blight pathogen
}

\author{
Jonathan Yuen ${ }^{1}$ \\ Received: 25 November 2020 / Accepted: 4 January 2021 / Published online: 15 January 2021 \\ (C) The Author(s) 2021
}

\begin{abstract}
Potato late blight, caused by Phytophthora infestans, is a critical disease of potato and other solanaceous crops, such as tomato. The history of late blight is, in some ways, the history of modern plant pathology. It received much attention in the mid 1800's by causing the Irish potato famine, and the pathogen played a prominent role in the development of the concept of plant disease and plant pathogens. The pathosystem has also been important in the development of pesticides that are active against plant pathogens, and has also been a model system in understanding concepts ranging from cellular processes, such as how resistance to plant pathogens functions, to large scale processes, such as implementation of regional plant disease warning systems. P.infestans has a secured a place in modern potato production, both in developed and less-developed countries.
\end{abstract}

Keywords Potato $\cdot$ Late blight $\cdot$ Economic importance $\cdot$ Management

While the disease late blight of potato, caused by Phytophthora infestans (Mont.) deBary is not the oldest documented plant disease in human history, it has accompanied many changes in the history of biology and agriculture. But prior to a discussion of the role this pathogen has had in my career and why I think it is an important and interesting pathogen, it may be well to explain a little about its biology, as we know it today. It is a well-known ailment in most potato production systems, and can cause catastrophic losses if left unchecked. The symptoms of late blight on potato leaves are water-soaked lesions (Fig. 1), often surrounded by a halo of white, downy sporangia, which are formed on sporangiophores (Fig. 2) that have emerged from the stomata of the leaves. These sporangia are easily dispersed by wind and water to other leaves, and after germination (either directly or via the release of a number of swimming zoospores) can cause new lesions in as short a time as three to four days. Sporangia that are washed off the leaves can also infect the potato tubers, giving rise to tuber blight or brown rot (Fig. 3). These infected tubers provide a survival route for the pathogen in the absence of sexual reproduction.

Jonathan Yuen

Jonathan.Yuen@slu.se

1 Swedish University of Agricultural Sciences, Uppsala, Sweden
If both mating types of the pathogen are found together sexual reproduction can take place and another type of spore, known as an oospore is formed, often in the leaves (Fig. 4). After desiccation and decomposition of the leaves, the oospores can survive several years in the soil, and infect potato plants. While the asexual form of the pathogen survives on potato tubers during the winter (or other periods when potato is not grown), the oospores, with their longer survival time, represent a source of inoculum that cannot be overcome by planting disease-free tubers. In addition, sexual reproduction from crossing different genotypes creates genetic variation in the pathogen.

While potato is the main food crop that can be infected by Phytophthora infestans, other crops in the Solanaceae can also be infected, such as tomato (Solanum lycopersicum) and eggplant (Solanum melongena). Disease on other crops, such as Solanum quitoense (naranjilla or lulo) or Solanum betaceum (tree tomato or tamarillo) has been reported as being caused by $P$. infestans sensu lato. This is complicated by the fact that $P$. infestans is a species complex and but it is unsure if these reports refer to $P$. infestans, Phytophthora andina (Oliva et al. 2010), or Phytophthora betacei (Mideros et al. 2018), species that are closely related to $P$. infestans.

I was a PhD student at Cornell studying plant pathology when I had my first real-life encounter with Phytophthora infestans. While I had seen the pathogen and the disease in different laboratory exercises, seminars, and lectures, it was in 


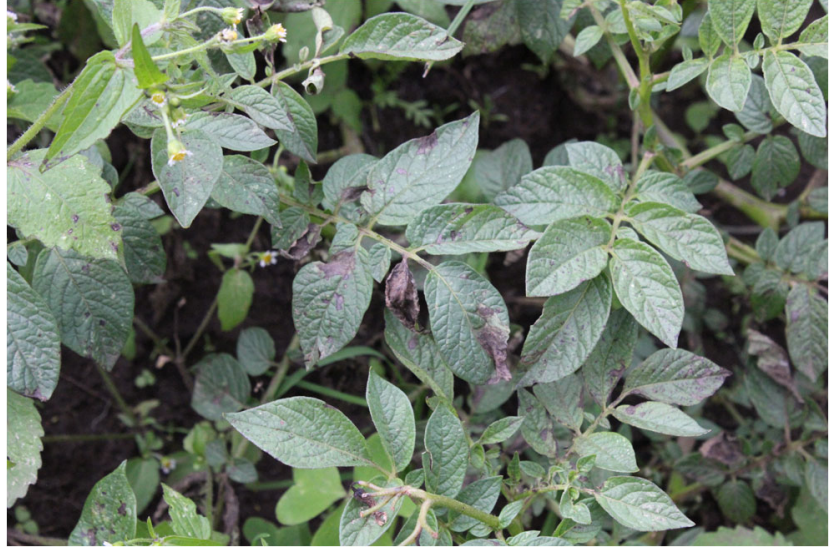

Fig. 1 Foliar symptoms of potato late blight, caused by Phytophthora infestans

my private garden plot, where we had planted potatoes, where I first met the pathogen on a personal basis. I can still remember the combination of the fascination that almost all plant pathologists have when they encounter a disease in real life, as well as the horror that struck me, since I knew that these potatoes were destined for a very untimely ending. The watersoaked lesions on the leaves were quite evident, and I could see the white spore masses that I knew would soon spread to the uninfected parts of the plants. My professional encounters with $P$. infestans had not yet started, but it was impossible not to be aware of the current research on the pathogen (much of it taking place at Cornell at that time) as well as the historical role it had played with regard to plant pathology and food security.

It was at the Asian Vegetable Research and Development Center (AVRDC) in Taiwan (now the World Vegetable Center) where I first tried working on late blight, but not on potatoes but on tomatoes. The Center was very much focused on tomato varieties with disease resistance, and I became aware that measuring resistance in a reliable and repeatable manner was of the utmost importance. At that time, I started

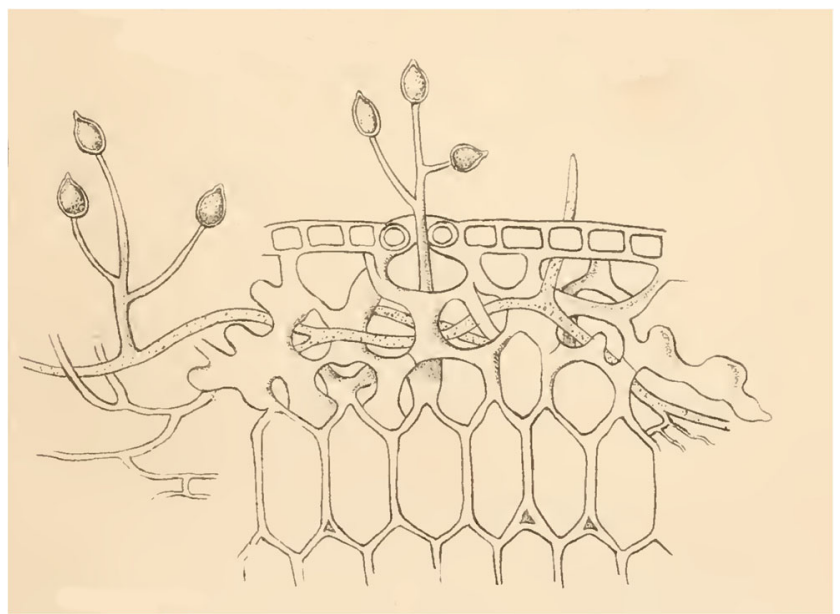

Fig. 2 Drawing of sporangia and sporangiophores from Berkeley 1846

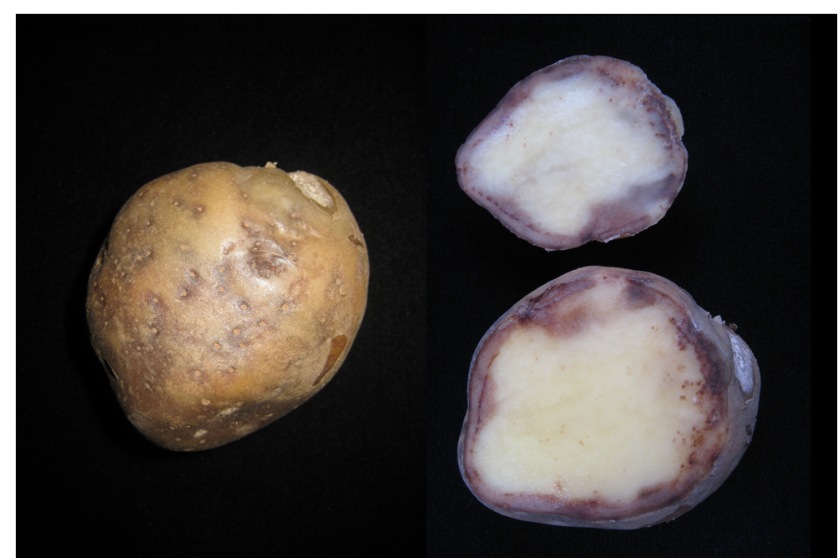

Fig. 3 Symptoms of tuber blight caused by by Phytophthora infestans

using epidemics of late blight in tomato plantings, which often needed assistance through overhead irrigation, as well as borders to prevent spores from moving between the different tomato cultivars. It was in Taiwan that I also realized the importance of proper diagnosis of a disease, after encountering recommendations to use fungicides specific for oomycetes like Phytophthora infestans, against what was clearly powdery mildew (which is caused instead by Leveillula taurica) on the tomato plants.

After the first years at AVRDC I was a post-doctoral scholar at the Swedish University of Agricultural Sciences (SLU) in Uppsala and was also looking into using plant disease epidemics of late blight to try and assess the levels of resistance in different potato cultivars. At the same time, there was interest in using simulation models of late blight, which had been developed at Cornell (Bruhn and Fry 1981). Coincidentally, the development of these models had started

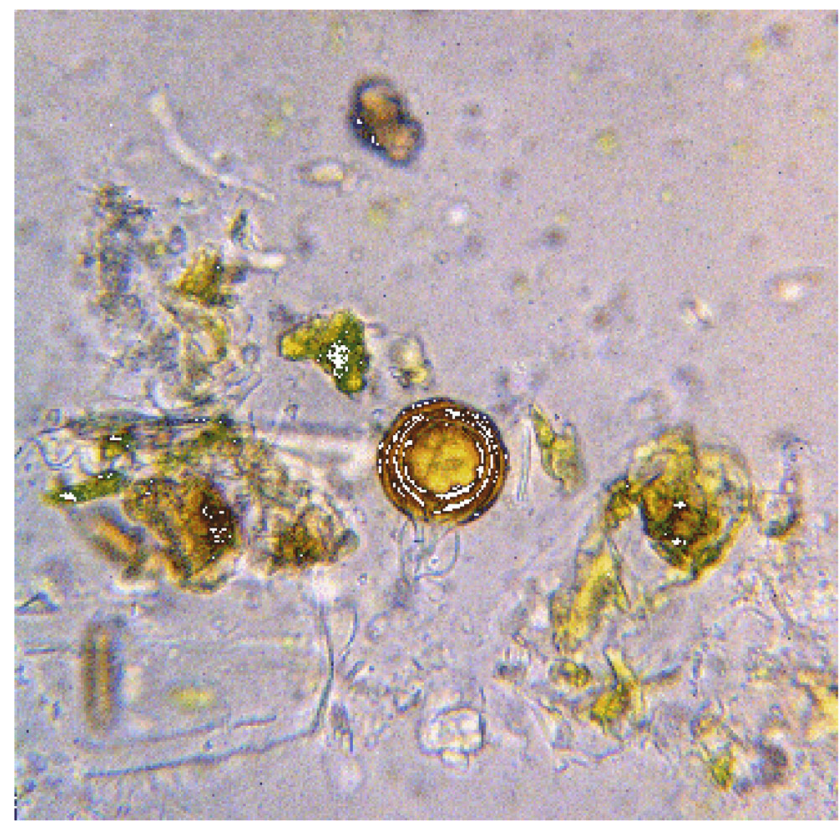

Fig. 4 Oospore of Phytophthora infestans 
during the period of time when I was there as a student. I knew they required different types of weather data, so collection of suitable (and sometimes unsuitable) weather data started. We never really did that much with the late blight simulation at that time, because the appearance of the A2 mating type in Sweden was perhaps of more interest (Kadir and Umaerus 1987). The conclusion at that time was that the appearance of the A2 mating type wasn't a major problem since it didn't seem to mate with the A1 mating type that was present in Sweden.

After a hiatus in Hawaii (working primarily with pineapples and no real interaction with Phytophthora infestans) and at Uppsala University (working with human disease epidemiology) I returned to the Swedish University of Agricultural Sciences just as early infections of potatoes with $P$. infestans became a problem. This occurred mainly in areas that specialized in production of early potatoes (harvested in June) and many farmers there grew potatoes repeatedly on the same sandy soil. Other strange patterns began to emerge, such as disease foci appearing in the same places every year. This, in conjunction with the early infections, which probably had taken place while the stems were still underground, led to the suspicion that the inoculum was soilborne (Andersson et al. 1998). Earlier infections also meant that the number of fungicide sprays for late blight control increased from 4 or 5 to maybe 9 or 10. I can remember how I realized how serious the problem was when I was at a grower meeting, where different field trials were being discussed. An experiment that included 15 different fungicide applications in one field plot was proposed, and none of the participants reacted. Late blight was not only an interesting scientific problem, but was also a major factor in potato production, and the days of 4 or 5 sprays (or even 1 or 2, which my wife's grandfather proposed in his 1937 book on potato production (Djurle 1939) were past.

I knew that oospores of Phytophthora infestans could be formed if both mating types were present, and the repeated disease foci in the fields was reminiscent of the foci I encountered with oospores of Bremia lactucae in upstate New York, when I was doing my $\mathrm{PhD}$ thesis. Fortunately, we were able to obtain funding for a Nordic late blight research project, which also coincided with an EU project on late blight. Use of molecular tools enabled us to study the $P$. infestans population extensively, not only in Sweden, but also in Latin America and Africa (Blandón-Diaz et al. 2012; Grönberg et al. 2012; Njoroge et al. 2019; Sjöholm et al. 2013; Widmark et al. 2011). The EU project (which has evolved into a longstanding cooperation within Europe) and contacts with the International Potato Center in Peru also fostered a global view of potato late blight.

While we have never actually observed oospores germinating and infecting potato stems in the field, either one has to accept that sexual reproduction of Phytophthora infestans takes place in northern Europe, or a very bizarre combination of unlikely events takes place, leading to the extreme withinfield variability and apparently soil- borne source of inoculum that we have seen in Scandinavia (Yuen and Andersson 2013). One puzzle that has yet to be solved is why the pathogen reproduces sexually in places such as Toluca, Mexico, and the Bjärö peninsula in Sweden. What do these two regions have in common that favours formation and subsequent germination of oospores followed by infection?

Did I make a logical choice to study Phytophthora infestans? I have commented to other plant pathologists that I seem to have chosen to study more traditional pathogens (in part because I have also had students that worked on leaf and stem rust). The criteria that determined what direction research took were twofold: one did what would deliver quick results, but one also did what was important. In some ways, the work on late blight seems to have fallen into the 'important' category, even though some parts of the research can give quicker results. Some of the more crucial questions still remain unanswered at this time (late 2020), such as how the oospores in the soil eventually infect the potato plant. It is also a critical pathogen with respect to potato production worldwide, and potato can play a major role in ensuring our future food security. The per-hectare caloric yields of potato are competitive with, or even exceed, those that can be obtained by cereal crops. This is why the Irish cottiers in the early 1800's grew almost exclusively potato on their tiny plots of land. It was the crop that could give them sufficient calories to survive, and it worked well until P. infestans arrived (Large 1940). When potato late blight struck Europe, it caused food shortages in many European countries, but poor people in Ireland were particularly hard hit due to their over-dependence on a single crop. According to some estimates, two million people died in Ireland due to the resulting famine, and another two million emigrated, a large number of them to the United States.. The 35th president of the USA, John F. Kennedy (Fig. 5), was a descendent of the Fitzgeralds, who migrated to the US between 1846 and 1855 to escape the famine caused by potato late blight.

If we examine these first well-documented epidemics of potato late blight, one can see the role that Phytophthora infestans played in a scientific revolution that changed how we view plant diseases. Scientific revolutions, as described by Kuhn (1970), have a number of characteristics, but the most prominent is a shift in paradigms, which come about when normal science, which builds on a body of previously accumulated knowledge, no longer functions due to increasing discrepancies in the results. Eventually these discrepancies can no longer be explained by the currently reigning paradigm, and a change (the scientific revolution) takes place, and a new paradigm replaces the old one. The paradigm shift that occurred was how disease occurred in plants. The older paradigm, favoured by botanists such as John Linley (Large 1940), was that plant disease (in this case the blight on the 


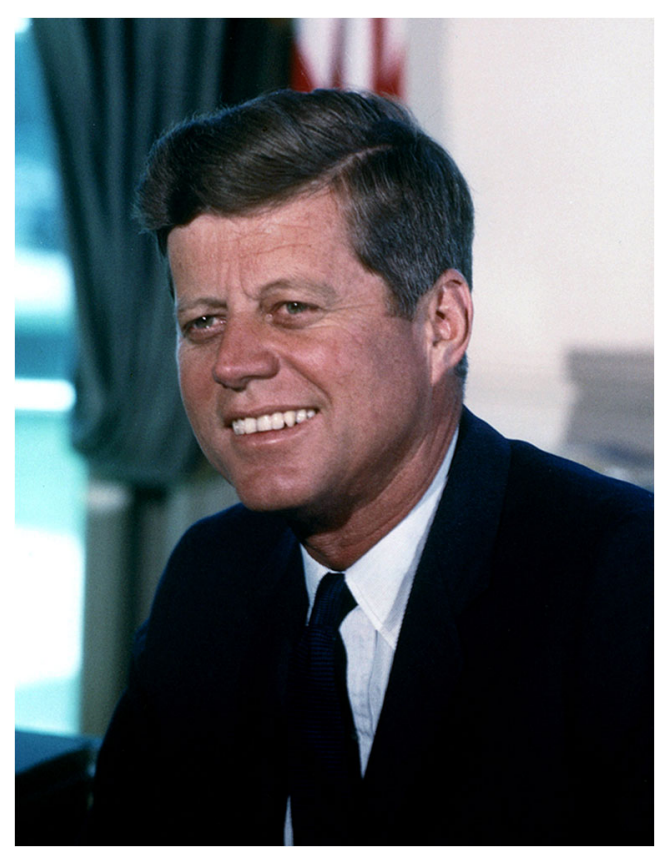

Fig. 5 John F. Kennedy, the 35th president of the US and descendent of immigrants escaping the potato late blight famine in Ireland

potato) was caused by a malfunction in the physiology of the plant. Repeated vegetative reproduction of the potato plant would also lead to some sort of physiological malfunctioning. While sporulation could be seen on these diseased potato plants, it was assumed that this was only a natural course of nature, since dead and decaying matter often had moulds that assisted in their decomposition.

Some scientists, led by the Rev. Miles Berkley were not satisfied with this explanation (Berkeley 1846). Too many facts about potato late blight could not be explained by bad weather and repeated vegetative reproduction of potato plants. Evidence accumulated as to the role of the spores that were observed on the potato leaves, and Anton deBary was able to reproduce the disease by shaking some of the spores from a diseased plant over healthy potatoes. A paradigm shift occurred, and one recognized that these micro-organisms could cause disease.

Another characteristic of scientific revolutions is that the vocabulary surrounding phenomena also changes. Disease was redefined to include something that was caused by these micro-organisms, and the word pathogen was then used to describe micro-organisms with disease-causing ability. Parallel to the development of this germ theory in plants was the development of a similar theory describing how microorganisms could cause disease in humans and animals.

The recognition that a micro-organism could cause a disease in a plant led to a search for a way to control the disease by attacking the pathogen. Despite early reports that potatoes growing near a copper smelting plant had less disease, it took the discovery by Millardet that a mixture of copper sulphate and lime was effective against a disease on grapes before this mixture, a copper based fungicide, was tried on potatoes, with good results. This initiated an alliance between potato production and fungicides (which we perhaps should call oomyceticides) that has persisted to this day. Potato is still one of the most heavily fungicide-treated crops. Potato is the food crop that receives the largest amount of pesticides per hectare in many developed (and even developing) countries. Fungicide use in developing countries can be more problematic, due to heavy applications of dithiocarbamates after the appearance of visible symptoms in an attempt to use the chemical in a more curative manner (Fig. 6). Large amounts of these chemicals are commonplace in potato-growing areas in Africa, such as Musanze in Northwest Rwanda (Fig. 7). Even in the twenty-first century late blight and its control accounts for $15 \%$ of the value of potato crops in well-developed production systems, based on projections from a study in the Netherlands that calculated the costs of control, primarily the application of chemicals (Haverkort et al. 2008). A reduction in the amount of chemicals used in late blight control could also carry with it environmental gains.

The search for late blight resistance in potato has also contributed to knowledge about more basic aspects of the plantpathogen interaction, on integration levels that range from the landscape level to recognition at the plant cell level. The role of Phytophthora infestans in spurring the search for better understanding was due to the wish to produce better types of resistance to the pathogen in commercially grown potato cultivars.

Some of the earliest systems for predicting the need of fungicide applications for control of plant diseases were for potato late blight (Beaumont 1947). While the early ones were simple rules using information on duration of certain temperature limits, and a similar measure for some sort of measure of humidity or leaf wetness, these systems have increased in complexity in order to reduce errors that might come about in making predictions for a single field (Bruhn and Fry 1981).

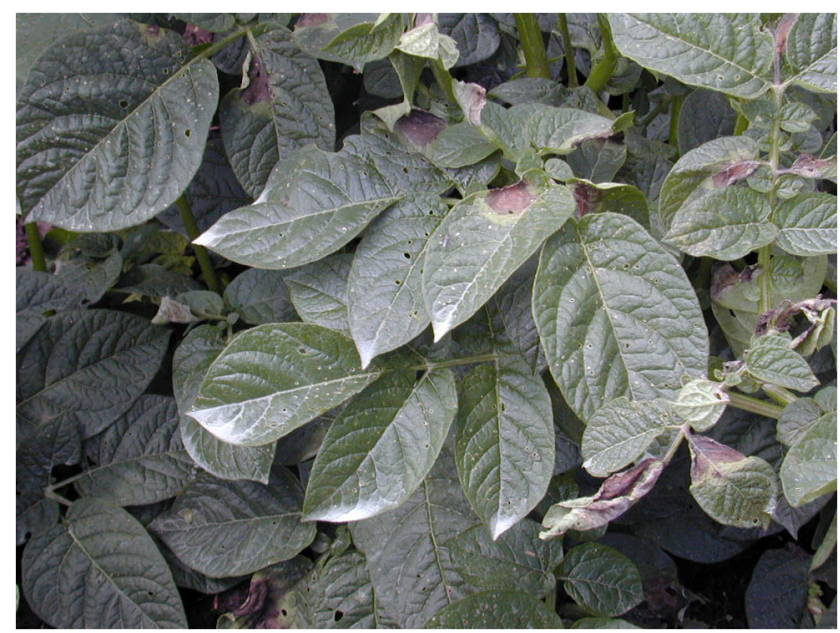

Fig. 6 Residues of mancozeb on infected leaves of potato 


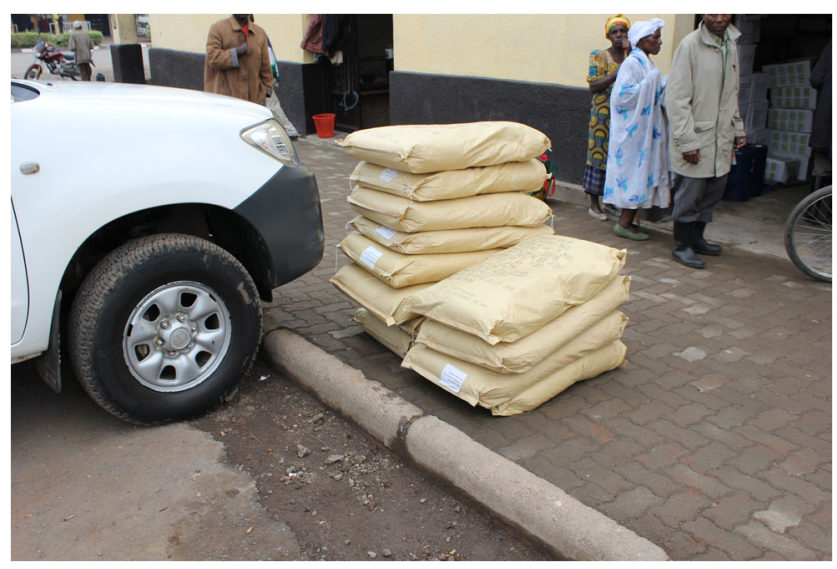

Fig. 7 Bulk deliveries of mancozeb at a chemical supply store in Musanze, Rwanda

Other developments in predictive systems have spurned prediction at a larger scale (Yuen and Mila 2015). Despite these improvements, the adoption of such predictive systems remains modest. One aspect is that the costs of the two types of errors that could be made with a system are unbalanced (Yuen and Hughes 2002). A false-positive (an un-needed fungicide application) has a relatively modest cost, compared to that of a false negative (missing a necessary spray could translate into the loss of an entire crop). Understanding how growers and decision-makers weigh the costs and risks of predictive systems could lead to better implementations of these systems.

Host plant resistance with genes from Solanum demissum was explored as a way to control potato late blight. Numerous varieties were bred with genes from this close relative of potato, and they initially showed little or no disease development when grown. This optimism was short-lived, however, and soon led to spectacular failures, due to the fact that some variants of $P$. infestans (despite its primarily clonal reproduction the pathogen can undergo a number of somatic genetic changes) were able to overcome the resistance that was conditioned by $S$. demissum genes in the potato. It was with this system that Vanderplank first described the terms 'vertical' and 'horizontal' resistance, based on figures in his book 'Plant Diseases-Epidemics and Control' (Vanderplank 1963). The fact that the presence of race-specific ('vertical') resistance genes can hinder selection for non-race-specific resistance ('horizontal') genes was also based on observations Vanderplank made of late blight epidemics, and he coined the 'Vertifolia effect' after the potato variety that exhibited these characteristics. Knowledge about effectors, their role in the plant infection and pathogen recognition, as well as their movement within the plant cells, is heavily based on studies of Phytophthora infestans.

Since the genome of Phytophthora infestans has been sequenced, a number of studies on the pathogen genome were also made possible. Genes in the pathogen that resemble the same pattern as the ones that respond to the 'vertical' ones from Solanum demissum have spurred the search for other sources of resistance in different Solanum species (Vleeshouwers et al. 2011). Even the International Potato Center (Centro Internacional de la Papa, CIP) has used GM technologies to incorporate resistance into conventional potato varieties in Africa (Ghislain et al. 2018). Still, as of this writing, GM potatoes face problems with consumer acceptance, and stiff regulation of GM food products. Even if the transgenic potato is accepted by the consumer, it is not clear whether $P$. infestans will not repeat what it has done with the other similar genes, and either dispose of, or modify, the corresponding effector, so that it can infect these GMO varieties. Several resistance genes could be packaged in a cassette but the optimal number of genes is still unknown. One could speculate that a better type of resistance is needed in potato production, one that is less likely to be overcome by changes in the pathogen. Whether it is incorporated into potatoes via GM technologies or conventional breeding is another matter.

As long as potato is part of the diet of humankind, the problems that arise from Phytophthora infestans will remain a factor in food security. Since the potato was one of the first crops treated with a fungicide, the production system has coevolved together with pesticides, and many potato cultivars require either regular applications of such a chemical, or possess resistance genes that may or may not work, depending on evolution and change of the pathogen. The failure of the 'vertical' resistance genes means that fungicide applications are inevitable. These factors have led, in turn, to breeding programs that do not necessarily select for durable plant resistance at the beginning, since so many other factors are desirable in a potato. Breeders select for characters related to marketability, such as yield, tuber size and appearance, knowing that the problems of late blight can be dealt with through the application of fungicides. Perhaps another type of breeding is needed if we are to wean the potato off repeated fungicide applications.

The evolutionary potential (McDonald and Linde 2002) of $P$. infestans is sufficient to ensure that it can overcome many resistance genes, and can also render some fungicides ineffective. One can speculate about what the future potato production and late blight management (and possible problems in management) might look like. Potato is a sufficiently large crop, globally, that one can be reasonably sure that fungicide development will take place, even in the future. Variation in the fungicide supplies, however, along with possible legislation that restricts the use of pesticides could lead to local problems in disease control. A local shortage of fungicides took place in the US in 2009 when late blight of tomato became widespread due to seedling infection at one of the main producers (Fry et al. 2013). Since agrochemical producers rely on estimates of potential needs, future situations could arise where there are insufficient amounts of fungicides required 
when severe late blight epidemics take place. Resistance in potato produced via GM technologies could provide a solution to late blight control, but it remains to be seen if this can be successful in the long term due to pathogen evolution as well as whether it will be accepted by consumers. One can be reasonably sure that some aspect of Phytophthora infestans will be a part of our future food security.

Funding Open Access funding provided by Swedish University of Agricultural Sciences.

\section{Compliance with ethical standards}

Conflict of interest The author declares that he has no conflict of interest.

Open Access This article is licensed under a Creative Commons Attribution 4.0 International License, which permits use, sharing, adaptation, distribution and reproduction in any medium or format, as long as you give appropriate credit to the original author(s) and the source, provide a link to the Creative Commons licence, and indicate if changes were made. The images or other third party material in this article are included in the article's Creative Commons licence, unless indicated otherwise in a credit line to the material. If material is not included in the article's Creative Commons licence and your intended use is not permitted by statutory regulation or exceeds the permitted use, you will need to obtain permission directly from the copyright holder. To view a copy of this licence, visit http://creativecommons.org/licenses/by/4.0/.

\section{References}

Andersson, B., Sandström, M., \& Strömberg, A. (1998). Indications of soil borne inoculum of Phytophthora infestans. Potato Research, 41(4), 305-310.

Beaumont, A. (1947). The dependence on the weather of the dates of outbreak of potato blight epidemics. Transactions of the British Mycological Society, 31(1-2), 45-53. https://doi.org/10.1016/ S0007-1536(47)80005-1.

Berkeley, M. (1846). Observations, botanical and physiological, on the potato murrain. Journal of the Horticultural Society of London, 1, 9-34.

Blandón-Diaz, J. U., Widmark, A. K., Hannukkala, A., Andersson, B., Högberg, N., \& Yuen, J. E. (2012). Phenotypic variation within a clonal lineage of Phytophthora infestans infecting both tomato and potato in Nicaragua. Phytopathology, 102, 323-330.

Bruhn, J. A., \& Fry, W. E. (1981). Analysis of potato late blight epidemiology by simulation modeling. Phytopathology, 71(6), 612.

Djurle, O. (1939). Potatisen-praktisk handbok för potatisodlare. Stockholm: Lantbrukssällskapets Tidskriftsaktiebolag.

Fry, W. E., McGrath, M. T., Seaman, A., Zitter, T. A., McLeod, A., Danies, G., Small, I. M., Myers, K., Everts, K., Gevens, A. J., Gugino, B. K., Johnson, S. B., Judelson, H., Ristaino, J., Roberts, P., Secor, G., Seebold Jr., K., Snover-Clift, K., Wyenandt, A., Grünwald, N. J., \& Smart, C. D. (2013). The 2009 late blight pandemic in the eastern United States - Causes and results. Plant Disease, 97(3), 296-306. https://doi.org/10.1094/PDIS-08-120791-FE.
Ghislain, M., Byarugaba, A. A., Magembe, E., Njoroge, A., Rivera, C., Román, M. L., Tovar, J. C., Gamboa, S., Forbes, G. A., Kreuze, J. F., Barekye, A., \& Kiggundu, A. (2018). Stacking three late blight resistance genes from wild species directly into African highland potato varieties confers complete field resistance to local blight races. Plant Biotechnology Journal, 17, 1119-1129. https://doi. org/10.1111/pbi.13042.

Grönberg, L., Andersson, B., \& Yuen, J. E. (2012). Can weed hosts increase aggressiveness of Phytophthora infestans on potato? Phytopathology, 102(ja), 429-433.

Haverkort, A. J., Boonekamp, P. M., Hutten, R., Jacobsen, E., Lotz, L. A. P., Kessel, G. J. T., Visser, R. G. F., \& van der Vossen, E. A. G. (2008). Societal costs of late blight in potato and prospects of durable resistance through cisgenic modification. Potato Research, 51(1), 47-57. https://doi.org/10.1007/s11540-008-9089-y.

Kadir, S., \& Umaerus, V. (1987). Phytophthora infestans A2 compatibility type recorded in Sweden. In $10^{\text {th }}$ Triennial Conference of the European Association for Potato Research (p. 223). Aalborg, Denmark.

Kuhn, T. (1970). The structure of scientific revolutions (2nd ed.). Chicago: University of Chicago Press.

Large, E. C. (1940). The advance of the fungi (488). London: Jonathan Cape.

McDonald, B. A., \& Linde, C. (2002). Pathogen population genetics, evolutionary potential, and durable resistance. Annual Review of Phytopathology, 40(1), 349-379. https://doi.org/10.1146/annurev. phyto.40.120501.101443.

Mideros, M. F., Turissini, D. A., Guayazán, N., Ibarra-Avila, H., Danies, G., Cárdenas, M., Myers, K., Tabima, J., Goss, E. M., Bernal, A., Lagos, L. E., Grajales, A., Gonzalez, L. N., Cooke, D. E. L., Fry, W. E., Grünwald, N., Matute, D. R., \& Restrepo, S. (2018). Phytophthora betacei, a new species within Phytophthora clade 1c causing late blight on Solanum betaceum in Colombia. Persoonia - Molecular Phylogeny and Evolution of Fungi, 41(1), 39-55. https://doi.org/10.3767/persoonia.2018.41.03.

Njoroge, A. W., Andersson, B., Lees, A. K., Mutai, C., Forbes, G. A., Yuen, J. E., \& Pelle, R. (2019). Genotyping of Phytophthora infestans in eastern Africa reveals a dominating invasive European lineage. Phytopathology, 109(4), 670-680. https://doi.org/10.1094/ PHYTO-07-18-0234-R.

Oliva, R. F., Kroon, L., Chacón, G., Flier, W. G., Ristaino, J. B., \& Forbes, G. A. (2010). Phytophthora andina sp. nov., a newly identified heterothallic pathogen of solanaceous hosts in the Andean highlands. Plant Pathology, 59, 613-625.

Sjöholm, L., Andersson, B., Högberg, N., Widmark, A.-K., \& Yuen, J. (2013). Genotypic diversity and migration patterns of Phytophthora infestans in the Nordic countries. Fungal Biology, 117(10), 722730.

Vanderplank, J. E. (1963). Plant disease: Epidemics and control (349). New York: Academic Press.

Vleeshouwers, V. G. A. A., Raffaele, S., Vossen, J. H., Champouret, N., Oliva, R., Segretin, M. E., et al. (2011). Understanding and exploiting late blight resistance in the age of effectors. Annual Review of Phytopathology, 49, 507-531.

Widmark, A. K., Andersson, B., Sandström, M., \& Yuen, J. E. (2011). Tracking Phytophthora infestans with SSR markers within and between seasons-a field study in Sweden. Plant Pathology, 60, 938-945.

Yuen, J. E., \& Andersson, B. (2013). What is the evidence for sexual reproduction of Phytophthora infestans in Europe? Plant Pathology, 62, 485-491. https://doi.org/10.1111/j.1365-3059.2012.02685.x.

Yuen, J. E., \& Hughes, G. (2002). Bayesian analysis of plant disease prediction. Plant Pathology, 51(4), 407-412.

Yuen, J., \& Mila, A. (2015). Landscape-scale disease risk quantification and prediction. Annual Review of Phytopathology, 53, 471-484. 


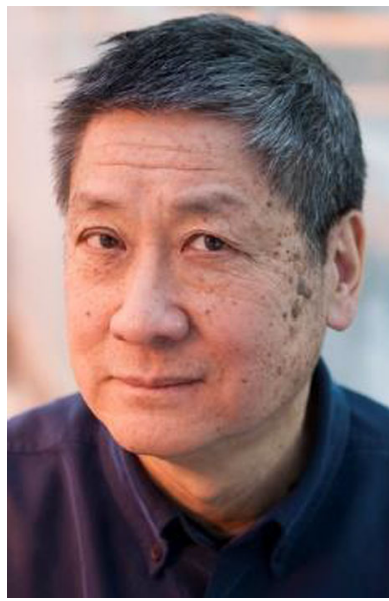

Jonathan Yuen was born in Washington, D.C., USA, but soon became interested in the role of agriculture in international development after his BA degree from the University of Chicago and a stint as a Peace Corps volunteer in Botswana. He received his $\mathrm{PhD}$ in plant pathology from Cornell University, and subsequently worked as a plant pathologist at the Asian Vegetable Center (now the World Vegetable Center) in Taiwan, the Swedish University of Agricultural Sciences (SLU) in Uppsala, Sweden, and the University of Hawaii. After working as a human disease epidemiologist at Uppsala University, he returned to the SLU, becoming professor, and retiring in 2017. His work in Sweden focused primarily on late blight and Phytophthora infestans, but he also worked on a number of rusts on wheat, oats, and barley. His interest in the role of agriculture and development continued at SLU, and he has had cooperative projects with both the International Potato Center (CIP) and the International Maize and Wheat Improvement Center. While retired from SLU, he still finds time to serve on the plant health panel of the European Food Safety Authority. 